\title{
Robert Winnicki
}

Uniwersytet w Białymstoku

\section{„Północ - to moja fabuła"1 \\ Polarne epifanie Jana Józefa Szczepańskiego i Mariusza Wilka}

Wydaną w 1960 roku Zatokę Białych Niedźwiedzi Jana Józefa Szczepańskiego można uznać za preludium do znakomitego, choć dziś niemal całkowicie zapomnianego cyklu podróżniczego, który stał się jednym z obszerniejszych rozdziałów twórczości autora Rafy². Reportaże Szczepańskiego, napisane z wyraźnym zacięciem antropologicznym, różniły się od innych podróżniczych relacji polskich pisarzy, którzy po październikowej odwilży i poluzowaniu polityki paszportowej również chętnie wyjeżdżali za granicę, publikując po powrocie relacje z tych peregrynacji. Szczepański wyruszał w dalekie i egzotyczne trasy, jakby nie do końca satysfakcjonowały go stereotypy i mity związane ze śródziemnomorskim dziedzictwem, jakby był znużony „dyżurnymi" tematami polskiego eseju czy reportażu podróżniczego. Indywidualnym rysem podróżniczych relacji Szczepańskiego, co podkreśla A. Werner w znakomitej monografii pisarza, był „całkowity brak rozważań typu [...]

1 M. Wilk, Dom nad Oniego, Warszawa 2006, s. 46.

2 Obok Zatoki... na cykl podróżniczy złożyły się następujące tomy reportaży: Do raju i z powrotem (1964) - owoc podróży Szczepańskiego do Afryki Północnej, na Bliski Wschód i do Indii; Czarne i białe (1965), relacjonujące wyprawę do Afryki; opublikowany w 1969 roku Świat wielu czasów, opisujący wędrówkę po Ameryce Środkowej i Południowej, a także Koniec westernu (1971), relacjonujący pobyt autora na stypendium w Stanach Zjednoczonych. Dopełnieniem cyklu stał się opublikowany w 1984 roku zbiór szkiców z podróży do Grecji i Meksyku pt. Nasze nie nasze. 
słoń a sprawa polska" ${ }^{3}$ - dość powszechny w książkach innych literackich globtroterów.

Blisko pół wieku dzieli wydanie Zatoki..., dokumentującej trzymiesięczny pobyt Szczepańskiego w polskiej bazie naukowej na Spitsbergenie, od publikacji Dziennika pótnocnego Mariusza Wilka ${ }^{4}$. Konfrontacja tych dwóch tytułów, spiętych wspólną klamrą doświadczenia dalekiej Północy, może posłużyć za interesujący przykład ilustrujący przemiany, jakim podróżniczy dyskurs uległ na przestrzeni ostatnich lat.

„Śmieci pod biegunem śmierdzą tak samo jak na warszawskim czy krakowskim podwórku" [ZBN, s. 53 $]^{5}$ - to jedno z pierwszych wrażeń odnotowanych przez autora Zatoki Białych Niedźwiedzi po przybyciu na Spitsbergen. Na pierwszy rzut oka cytat ten wygląda na prowokacyjny chwyt literacki, na chęć zaskoczenia czytelnika oryginalnością spostrzeżeń. Ale można go też potraktować jako trzeźwą i rzeczową obserwację kogoś, kto zdawał sobie sprawę, że współczesna ekspedycja naukowa jest przedsięwzięciem dalekim od romantycznych wyobrażeń. Przygoda szybko zamienia się bowiem w nużącą rutynę. Warto zwrócić uwagę na fakt, że przywołana scena niemal do złudzenia przypomina początkową sekwencję głośnego filmu dokumentalnego Wernera Herzoga pt. Spotkania na krańcach świata, w której reżyser po wylądowaniu na Antarktydzie przeżywa konsternację na widok amerykańskiej bazy Mc Murdo. Zamiast nieskazitelnej bieli lodowców widzi ciężarówki i koparki grzęznące $w$ błocie, zamiast poetyckich pejzaży - cywilizacyjny śmietnik. Przyznaje, że nie spodziewał się romantycznych krajobrazów ani ludzi żyjących w harmonii z puchatymi pingwinami, ale nie sądził, że zobaczy w tym miejscu górnicze miasteczko.

Choć Arktyka pod koniec lat pięćdziesiątych nie była aż tak zindustrializowana, autor Zatoki Białych Niedźwiedzi był nie mniej zaskoczony niż słynny niemiecki reżyser tym, co ujrzał. Pejzaż w niektórych miejscach przypominał bardziej górniczy krajobraz Śląska aniżeli mroźnej Północy: „Pod naszymi stopami zaś otwierała się obszerna, wielokilometrowej średnicy niecka błotnistego niechlujstwa, hałd, rozpadlin, kałuż, mętnych ścieków, smutnych ugo-

3 Zob. A. Werner, Wysoko. Nie na palcach. O pisarstwie Jana Józefa Szczepańskiego, Kraków 2003, s. 68 .

4 Dziennik pólnocny stanowi cykl, na który składają się następujące tomy: Dom nad Oniego (2006), Tropami rena (2007), Lotem gęsi (2012). Fragment Dziennika pótnocnego znalazł się również w Wołoce (2005).

5 W ten sposób odsyłam do J. J. Szczepańskiego, Zatoka Białych Niedźwiedzi, Kraków 1960. Ponadto stosuję następujące skróty cytowanych utworów M. Wilka: Tropami rena, Warszawa 2007 [dalej - TR z numerem strony]; Dom nad Oniego, Warszawa 2006 [dalej - DO z numerem strony]; Wołoka, Kraków 2005 [dalej - W z numerem strony]. 
rów. Jak gdyby kawał sponiewieranej przez człowieka, wyzyskanej chciwie, a potem porzuconej ziemi Śląska czy Ruhry" [ZBN, s. 109]. Symptomatyczny jest fakt, że od takich obrazów rozpoczął swój opis Arktyki Szczepański. Dostrzec można w tej poetyce wyraźnie zaznaczoną intencję. Autor Kipu na kartach Zatoki..., podobnie jak Werner Herzog, próbował skruszyć romantyczny mit polarnych krain, które zwykle przedstawia się jako „wspaniałe i groźne”. W rzeczywistości natomiast odarte są z przypisywanego im uroku, zwykle rozczarowują, nie wpisując się $\mathrm{w}$ potoczne oczekiwania ani utarte wyobrażenia. Karel Čapek w kapitalnych Listach z podróży również przyznawał, że pierwsze spojrzenie na strefę polarną bardzo rozczarowuje, przynosząc zazwyczaj głęboki emocjonalny zawód: „Niby to ma być ta polarna kraina? To nie jest uczciwa gra" ${ }^{6}$. Nie da się oddać kolorytu, smaku tych stron, zawężając opis jedynie do tego, co uznawane jest za piękno świata. Dlatego relacja ze Spitsbergenu przybrała formę ostentacyjnie wręcz nieromantyczną.

Arktyka, o czym warto wspomnieć, nie była białą plamą na mapie polskiej literatury. Jej obraz $\mathrm{w}$ oczach rodzimego czytelnika ukształtowały przede wszystkim książki Aliny i Czesława Centkiewiczów. Największą popularność zdobyły Na podbój Arktyki oraz reportażowa Wyspa mgieł $i$ wiatrów dokumentująca pobyt Czesława Centkiewicza na Wyspie Niedźwiedziej. Charakterystyczny jest fakt, że Szczepański tylko w jednym miejscu odwołuje się do Centkiewicza, wówczas, kiedy spotyka sportretowanego w jednej z jego książek wielkiego przyjaciela polskich polarników - telegrafistę Fritza Öyena. Dlaczego Szczepański nie chciał wpisywać się w kontekst tekstów Centkiewiczów? Prawdopodobnie dlatego, iż funkcjonowali oni w odbiorze czytelników, a także krytyków, jako „autorzy dla młodzieży”. Ich książek, choć cieszyły się one sporą popularnością i nie były skądinąd pozbawione pewnych literackich walorów, nikt nie traktował zbyt serio ani za wysoko nie cenił.

Chociaż Zatoka... jest osobną całością, zarysowuje się w niej swoisty sposób widzenia obcych krain, charakterystyczny dla późniejszych tekstów reportażowych, który w Do raju i z powrotem autor określił mianem „demaskacji egzotyki". Wrażliwość na egzotykę powinna być jedynie zaproszeniem do szukania prawdy [ZBN, s. 8]. I właśnie tej surowej, nielukrowanej, często trudnej do przyjęcia prawdy o świecie pisarz szuka również w dalekiej Arktyce. Nie chce zamykać oczu na jej brzydotę, kiedy podkreśla, że wszyscy, którzy opisują piękno polarnych krain, zafałszowują ich obraz, przemilczając z reguły np. moreny umierających lodowców. W rzeczywistości na

${ }^{6}$ K. Čapek, Listy z podróży, przeł. P. Godlewski, Warszawa 2011, s. 445. 
morenie można utopić się $\mathrm{w}$ błocie, ale ten fakt nie jest dostatecznie efektowny, aby o nim wspominać. Romantyczna wizja rzeczywistości, co autor wielokrotnie akcentował w swojej prozie podróżniczej, okazuje się zwykle bardzo niepełną, fragmentaryczną wiedzą o świecie.

\section{Tabula rasa}

Powstaje oczywiście pytanie, czego tak naprawdę szukał Szczepański za kołem podbiegunowym? Jakich wtajemniczeń albo jakich olśnień? Czego spodziewał się po tej wyprawie? Zadane na początku pytanie: „co ja tutaj robię" - dalekim echem pobrzmiewa w całej książce, zyskując często wydźwięk egzystencjalny. Pobyt na Spitsbergenie pisarz traktował jako swoisty „urlop od czasu”, możliwość zanurzenia w rzeczywistości, w której obowiązywały odmienne prawa i która narzucała inny rytm wewnętrzny. Specyfika wyprawy na Spitsbergen polegała wszakże nie na grach z czasem, ale przede wszystkim na tym, że okazała się, choć zabrzmi to może nazbyt patetycznie, konfrontacją z pustką - zarówno w planie fizycznym, jak i duchowym. Przede wszystkim z pustką bezmiernych lodowych przestrzeni, pośród których człowiek czuje się intruzem, gdzie natura nie zwraca na niego najmniejszej uwagi: „Otwierała się przed nami ogromna, pełna wspaniałej surowości pustka. Wkraczało się $\mathrm{w}$ nią $\mathrm{z}$ uczuciem ucisku $\mathrm{w}$ gardle - jakby nie dowierzając własnemu zuchwalstwu" [ZBN, s. 20]. W wymiarze poznawczym wyprawa na Spitsbergen oznaczała konfrontację z rzeczywistością, do której nie dawało się przyłożyć żadnych zastanych miar czy analogii, pozostającą zasadniczo poza zasięgiem intelektualnej percepcji. Szczepański nie czuł się dumnym zdobywcą odległych krain, cały swój pobyt za kołem polarnym opisywał w kategoriach zagubienia, jako wysiłek dość rozpaczliwego i na ogół nieskutecznego poszukiwania jakichkolwiek układów odniesienia lub choćby odległych punktów zaczepienia. Problem polegał na tym, że polarnego doświadczenia nie udawało się wpisać w żadną dostępną ramę kulturową, $\mathrm{w}$ jakikolwiek adekwatny kontekst. Była to sytuacja bez precedensu, autor nie przeżył podobnego doświadczenia, przynajmniej w takiej skali, podczas każdej następnej wyprawy. Trudność ze znalezieniem klucza do Spitsbergenu polegała również na tym, że nikt go nie malował, że nie funkcjonował w żadnej tradycji ikonograficznej. Widzenie Szczepańskiego jest zwykle zapośredniczone przez imaginarium sztuki, nie potrafi się od niego odciąć. Sztafaż kulturowy składa się na pewną przedwiedzę, niezbędną do uczuciowego kontaktu z oglądanymi w podróży miejscami i zabytkami. Jego percepcja pogłębiona zostaje w zetknięciu z obrazami coś już przypominającymi, 
kojarzonymi kulturowo. Arktyczna natura nie daje się w ten sposób czytać - „żyje i umiera bowiem bez świadków” [ZBN, s. 109]. Tym, co otacza człowieka, jest tutaj jedynie przejmująca "cisza martwej ziemi" [ZBN, s. 139].

Spitsbergen jest fenomenem, funkcjonuje bowiem jako tabula rasa, samotna wyspa, jedno z ostatnich dziewiczych miejsc na Ziemi, wyjętych spod praw działania czasu i historii. Jest $\mathrm{w}$ jakimś sensie miejscem nie-ludzkim: „A Spitsbergen żyje swoim własnym, geologicznym i zwierzęcym życiem. Chociaż poznaczony śladami ludzkimi, jest bezludny, prawie $\mathrm{w}$ ogóle nie uwikłany jeszcze w historię, która muska go zaledwie luźnym ściegiem, jak fastryga rzucana od przypadku do przypadku" [ZBN, s. 80-81].

Spitsbergen można nazwać „ziemią jałową", na której trwa wieczne „teraz". Wrażenie to potęgował fakt, że trzymiesięczny pobyt naukowców przypadał na okres lata i był jednym wielkim dniem polarnym. Ale przytoczone rozważania sięgają głębiej, są jednym z kluczowych fragmentów całej książki, stanowią istotny punkt dojścia refleksji autora. Zarysowuje się tu koncepcja historii, która zakłada ciągłość i racjonalność ludzkich działań. Jawi się ona $\mathrm{w}$ tym ujęciu jako pewna intencjonalna całość obdarzona sensem, stanowiąca depozyt ludzkich tęsknot i wysiłków, dlatego tworząca naturalne środowisko człowieka. Arktyczne twory natury okazują się ostatecznie tylko pięknymi widokami, które ogląda się niczym pocztówkę lub efektowny landszaft. Działają bezpośrednio na zmysły, ale nieprzefiltrowane przez odmienną wrażliwość pozostawiają w gruncie rzeczy obojętnym tego, kto na nie patrzy. Dlatego człowiek bardzo łatwo do nich przywyka i - paradoksalnie - szybko przestaje na nie reagować. Tomasz Burek dostrzegł nawet $\mathrm{w}$ samym wyborze miejsca wyprawy „zdradę" autora: „Tam, gdzie do głosu dochodzi «złe sumienie» pisarza i zmusza go do znajdywania usprawiedliwień dla owego osobliwego «urlopu od czasu», jakim była podróż, nie mamy wątpliwości, że pisał tę książkę autor Polskiej jesieni; wstyd mu, że za spotkanie z białym niedźwiedziem musi płacić niewspółmierną ceną: zdradą, przeniewierstwem w stosunku do jedynie obchodzącego go tematu, którym jest dlań - los człowieka uwikłanego w dramat historii" 7 .

Przebywając $\mathrm{w}$ bazie, autor miał poczucie, że właściwie cały czas żył "pod polskim kloszem”, obracając się w kręgu rodzimej mentalności, języka, nawyków. Wśród arktycznych pustkowi nie miał szans na doświadczenie uczucia obcości, które było nieodzownym składnikiem jego podróżopisarstwa [ZBN, s. 81]. Człowiek w arktycznym pejzażu mógł czuć się co najwyżej natrętnym gościem, który naruszył odwieczny ład.

7 T. Burek, Podróż bez romantyzmu, „Twórczość” 1961, nr 3, s. 115. 


\section{Polarne epifanie}

Wydawać by się mogło, że okoliczności sprzyjały temu, aby wsłuchać się $\mathrm{w}$ tę dojmującą ciszę, przenosząc punkt ciężkości opisu ze świata zewnętrznego w głąb samego siebie. Spotkanie z majestatyczną, choć zarazem surową naturą, stwarzało idealne tło dla introspekcji, medytacji, dla snucia dywagacji o przygodach duszy. Dłuższy pobyt na Spitsbergenie nie stał się jednak pretekstem do odbycia jakiejś formy wewnętrznych „rekolekcji”. Trudno przynajmniej odnaleźć ich ślad w tekście. Może cała sytuacja stałaby się zanadto romantyczna, za bardzo kojarzyłaby się z konwencją Friedrichowych malowideł przedstawiających "samotnych wędrowców wśród gór", a Szczepański jak ognia unikał wszelkich póz, przesady, teatralizacji. A może przeżycia były zanadto intymne... Warto zauważyć, że to jedyny reportaż cyklu podróżniczego, w którym nie pojawiają się wątki religijne czy metafizyczne. Co prawda w innych książkach podróżniczych Szczepańskiego religia traktowana była zwykle jako klucz do zrozumienia obcych kultur, a nie jako doświadczenie wewnętrzne. Pisarz uważał się bowiem za sceptyka, może nawet agnostyka, choć jego niejednoznaczny, skomplikowany stosunek do wiary wart byłby osobnego, pogłębionego studium. Szczepański w licznych utworach krążył bowiem nieustannie wokół sfery sacrum, szukał metafizycznego wymiaru istnienia, ale bez gwarancji, bez poręczenia jakiegokolwiek systemu religijnego. Reprezentował indywidualistyczną koncepcję odpowiedzialności etycznej wobec ludzi, własnego sumienia, a w ostatecznej instancji wobec "Nieznanego Trybunału”.

W Zatoce... Szczepański pozostał bardzo powściągliwy i dyskretny w opisywaniu swoich przeżyć, w tym również duchowych, co stanowi cechę charakterystyczną wszystkich jego reportaży podróżniczych. Zresztą nie tylko relacji podróżniczych, ale właściwie całej twórczości, której emocjonalną aurę Andrzej Werner zawarł w lapidarnej formule: „Skromność, powściągliwość, wstydliwość" ${ }^{\prime \prime}$. Szczepański był zwykle wycofany, nie wysuwał się na pierwszy plan, rzadko się odsłaniał. Może za rzadko - zwłaszcza z punktu widzenia naszych dzisiejszych czytelniczych przyzwyczajeń i oczekiwań. Niewykluczone, że w tym nieco staroświeckim przywiązaniu do emocjonalnej powściągliwości i umiaru tkwi jedna z przyczyn zapoznania twórczości autora Kadencji. Ale była to świadoma decyzja, którą konsekwentnie realizował w całej swojej prozie. Na przełamanie tej konwencji, na odsłonięcie sfery osobistych doznań, decydował się tylko w wyjątkowych okolicznościach -

8 A. Werner, Wysoko. Nie na palcach, s. 119. 
w chwilach, które można określić mianem epifanii, „małych iluminacji”, jak choćby $\mathrm{w}$ opisie radosnego uniesienia po powrocie $\mathrm{z}$ brawurowej wyprawy na lodowiec i grań Luciakammen: „Oczy piekły jeszcze dotkliwie, ręce poruszały się niezdarnie, zesztywniałe ciało wydawało się nie całkiem własne, lecz wewnątrz wzbierała fala ogromnej, podniecającej radości. Chciało mi się śmiać, jak gdybym odkrył w sobie nieprawdopodobną i nigdy w pełni nie docenianą rozkosz istnienia. $W$ tym momencie nie miałem wątpliwości, że przyjechałem tu po to właśnie olśnienie" [ZBN, s. 168-169].

Na lodowcu autor przez moment odnalazł dobrze znany smak taternickiej przygody. Górska pasja była w pisarstwie Szczepańskiego niezwykle ważnym i często powracającym motywem, stawała się wiele razy pretekstem do wychylenia ku rzeczywistości metafizycznej. Góry, zdaniem A. Wernera, są dla Szczepańskiego „w przybliżeniu tym, czym morze dla Conrada. Tyle, że bez jakiejkolwiek ostentacji, bez jawnego symbolizowania" ${ }^{9}$. A. Sulikowski w podróżach Szczepańskiego po świecie, prowadzących przez pasma Andów czy góry w Afryce Południowej, dostrzegał uporczywe poszukiwanie reminiscencji pierwszych „wyjść w Tatry”, pierwszych powrotów ze ściany: „Są to wrażenia silne, przenikliwe do tego stopnia, że można mówić o «archetypie tatrzańskim» w całej twórczości" ${ }^{10}$.

W opisywanych przez autora chwilach olśnienia z jakąś niezwykłą intensywnością objawiała się prawda istnienia, odsłaniała się, choćby na moment, tajemnica bytu, a także tęsknota za duchową czystością, przejrzystością wewnętrzną, za stopieniem się w jedno z naturą. Góry stały się nie tylko azylem, ale również „oknem” na inny wymiar rzeczywistości. Te momenty łaski, intensywnego odczuwania pełni istnienia są ze swej natury niezwykle rzadkie, migotliwe, ulotne. Nadają jednak sens życiu, decydują o jego smaku - warto na nie czekać, stanowią też o sensie pisania. Są momentem iluminacji, dają intuicyjny ogląd "podszewki" świata. Owe chwile pełni zdarzają się z reguły nieoczekiwanie, zwykle nic ich nie zapowiada, są trudne do wyrażenia w słowach, pozostawiają jednak po sobie trwały ślad w duszy, dlatego tęskni się do nich, często też powracają we wspomnieniach. Fragmenty opisujące podobne przeżycia stanowią o niepowtarzalnym smaku prozy Szczepańskiego, która w swej istocie jawi się jako głęboko kontemplacyjna: „Nie działo się nic, co zasługiwałoby na miano przeżycia. Lecz wszystko to nasycało po brzegi czas uczuciem pełni, uczuciem sensu. Może nie potrafię tego wyrazić ani wytłumaczyć dostatecznie, dlaczego o tym wspominam i dlaczego o tym

\footnotetext{
9 Tamże, s. 34.

10 A. Sulikowski, Wyjście w góry. Dwie postawy - Karol Wojtyła i Jan Józef Szczepański, w: Twórczość literacka i filmowa Jana Józefa Szczepańskiego, red. S. Zabierowski, Katowice 1995, s. 19.
} 
pamiętam. Wydawało mi się jednak, że zostałem dopuszczony do źródeł wielkiego spokoju Borcha" [ZBN, s. 186-187].

Borch jest jedną $\mathrm{z}$ najciekawszych postaci sportretowanych $\mathrm{w}$ Zatoce.... Ten norweski szyper, „morski chłop z kutrem zamiast furmanki” [ZBN, s. 181], sezonowo zajmujący się łowiectwem, wyjęty był jakby z innej epoki. Szczepański nazywa go „zabytkiem” i „ostatnim Mohikaninem”. Żył na łasce natury, w zgodzie ze sobą. Mógł się uchować tylko na dalekiej Arktyce, ale nawet tutaj jego świat stawał się już reliktem przeszłości i był skazany na kapitulację, jak wszystko, co rozproszone, drobne, pozbawione dynamiki. „Myślałem o tym z żalem, bo ów skazany na zagładę spokój wydawał mi się zawsze rzeczą godną ocalenia, może nawet niezbędną, jak balast, utrzymujący w równowadze ludzkie społeczeństwa" [ZBN, s. 182].

Spokój jest pojęciem często przewijającym się w tekstach autora Przed Nieznanym Trybunatem. Oznacza uprzywilejowany i w gruncie rzeczy upragniony stan zgody ze sobą, będący swoistą łaską. Może jego istota sprowadzała się do tego, że Borch miał w sobie pewien wewnętrzny kompas, którego my, jako ludzie skażeni cywilizacją, zostaliśmy już pozbawieni. Widziana z perspektywy czasu postać Borcha urosła do rozmiarów niemal mitycznych, autorowi wydawało się, że prowadził z nim głębokie, długie rozmowy, choć w rzeczywistości szyper mówił tylko po norwesku. Być może nie miał nawet nic istotnego do powiedzenia. Nie chodziło tu wbrew pozorom o naiwną idealizację "prostego człowieka” czy wiarę w moralnie uzdrawiającą moc jakiejś formy „powrotu do natury”. Szczepański nie miał złudzeń, nie wierzył w możliwość odzyskania raz utraconej arkadii. Zdawał sobie sprawę, że cywilizacja oferuje bilet tylko w jedną stronę.

\section{Polarny impresjonizm}

Sporo miejsca w Zatoce Białych Niedźwiedzi zajmują partie opisowe. Pejzaż arktyczny jest surowy, taki też, jak mogłoby się zdawać, powinien być jego literacki obraz. Burek podkreślał, że Szczepański „wyzwala pejzaż z wyzłoconych naszymi złudzeniami ramek; maluje go wąską skalą barw, zgaszonymi tonami, bez cienia kokieterii i przesady"11. O ile wątpliwości nie budzi końcowa część komentarza wybitnego krytyka, o tyle trudno zgodzić się z opinią o "wąskiej skali barw i zgaszonych tonach”. Szczepański, na co zbyt rzadko zwraca się uwagę, był mistrzem plastycznego, niezwykle sugestywnego opisu o dużej sile wyrazu, z którego umiał wydobyć nastrój,

11 T. Burek, Podróż bez romantyzmu, s. 116. 
detal, smak chwili. Na miano stylistycznego popisu zasługuje choćby poniższy fragment, znakomicie ilustrujący, jak świetnym pejzażystą potrafił być Szczepański, jak plastycznie i wyraziście potrafił swoje iluminacje zapisać: „Pozostawione na południu zwały chmur lśniły w blasku słońca jaskrawym, czystym fioletem. Każde najdrobniejsze załamanie lustra wody było gładką soczewką, kołyszącą eliptycznie wydłużone plamy przeźroczystych kolorów - od fioletowego poprzez złotawy róż aż do ciepłego kadmu. Nawet powietrze wydawało się nasycone subtelnym oparem złota. Milczeliśmy, przeniknięci radosną powagą" [ZBN, s. 155]. Milczenie jest symbolem postawy kontemplacyjnej, ukorzenia wobec majestatu natury. Arktyka jawi się tutaj jako zjawiskowa, fantasmagoryczna, nierealna.

\section{Bez egzotyki}

Spitsbergen okazał się ostatecznie nie do uchwycenia. W pewnym sensie wyprawa na koło podbiegunowe rozczarowała pisarza, ale pozwoliła mu via negativa - zdać sobie sprawę z tego, czego tak naprawdę szukał, a czego nie udało mu się odnaleźć na dalekiej Północy. Na tle pozostałych książek podróżniczych Szczepańskiego Zatoka... wyraźnie odznacza się tonem rezygnacji, bezradności epistemologicznej. W pewnym sensie jest raportem z nieudanej wyprawy, przyznaniem się do własnej bezsilności poznawczej. Arktyka udzieliła pisarzowi lekcji pokory, ale też wskazała kierunek kolejnych poszukiwań. Na Spitsbergenie zabrakło tego, co stanowić będzie żywioł podróżniczej prozy Szczepańskiego - poczucia obcości wynikającego z zetknięcia z inną kulturą, inną tradycją, cywilizacją. Mimo wszystko, opuszczając Arktykę, pisarz był bogatszy o cenną wiedzę, że w ostatecznym rachunku „tylko odmienność cywilizacji stwarza atmosferę tajemnicy. Tylko ludzie mogą być nosicielami prawdziwej egzotyki" [ZBN, s. 150].

Trudno oprzeć się wrażeniu, że Zatoka... jest książką, w której ujawnia się pewne pęknięcie. Tak jakby autor nie mógł się do końca zdecydować, czy chciał napisać reportaż o trudzie polarników, pochwałę walki człowieka z żywiołami przyrody, czy raczej miały to być refleksyjne zapiski samotnego wędrowca, który mierzył się z nieprzystępnym i mrocznym światem natury. Jeśli czytana po latach Zatoka... mimo wszystko się broni, to przede wszystkim dzięki głębszym obserwacjom, rzucanym jakby od niechcenia refleksjom na temat natury czasu, chwilom kontemplacji. Całość naznaczona jest też pojawiającym się $\mathrm{w}$ licznych fragmentach charakterystycznym dla pisarstwa Szczepańskiego osobistym, czasem filozoficznym tonem. Trafnie ujął to T. Burek w jednej z ciekawszych recenzji Zatoki..., gdzie pisał, że na 
jej zdawkowe potraktowanie „nie pozwala właśnie ten ledwo zaznaczony szkic, zarys myśli [...] ten brulion zawsze współczesnych problemów humanizmu, drogocenny brulion wklejony na chybił trafił między kartki turystycznego albumu"12. Mimo komplementowania urody literackiej, wymowne jest określenie książki mianem „brulionu” i „turystycznego albumu”. Brulion to przecież luźny notatnik, właściwie brudnopis. Przy wszystkich powyższych zastrzeżeniach, podkreślić należy, że autor pozostał wewnętrznie uczciwy, nie próbował "podkolorować” swoich wspomnień, nie uciekł w efekciarskie opisy. W żadnej relacji z podróży Szczepański nie wpadł w drażniącą manierę wielu, zwłaszcza współczesnych, literackich globtroterów, rozpościerających przed czytelnikiem aurę wtajemniczenia. Wyprawa na Spitsbergen była swoistą literacką mission impossible. Trudno założyć, że ciekawszą książkę o Arktyce zdołałby napisać Ryszard Kapuściński, a tym bardziej Zbigniew Herbert. W bezkresnej, jałowej przestrzeni dalekiej Arktyki być może lepiej odnaleźliby się Andrzej Stasiuk lub Mariusz Wilk - specjalizujący się w efektownym opisywaniu pustki, opiewaniu miejsc zapomnianych przez Boga i ludzi, zastygłych w odwiecznym kształcie.

\section{Barbarzyńca w krainie Saamów}

Tropami rena - drugi tom Dziennika pótnocnego - Mariusza Wilka można odczytywać, co podkreślali już pierwsi recenzenci książki ${ }^{13}$, jako swoisty rewers Barbarzyńcy w ogrodzie Zbigniewa Herberta. Autor Wołoki odwołuje się zresztą bezpośrednio do pamiętnego eseju Herberta o skalnych malowidłach w Lascaux, dokonując rekonstrukcji genealogii Saamów, koczowniczego plemienia mieszkającego za kołem podbiegunowym, którego miejsca narodzin niektórzy badacze doszukują się w Europie, w grotach Altamiry i Lascaux. W przeciwieństwie do Herberta - Wilka nie interesują jednak źródła kultury, w historii Saamów akcentuje pierwiastki nieokiełznania, pierwotności, wolności: „Autor Barbarzyńcy w ogrodzie - konstatuje P. Małochleb - badając Lascaux, szuka pierwszych przejawów kultury, tymczasem Wilk w swoim widzeniu rytów naskalnych Kujwy, podkreśla to, co w człowieku zwierzęce, nieujarzmione, a przede wszystkim nieprzekładalne na język, niewypowiadalne"14. Wilk, podobnie jak Herbert, redefiniuje również kategorie swojskości i obcości. Z tym, że autor Barbarzyńcy... utożsamiał się

\footnotetext{
12 Tamże, s. 115.

13 Zob. P. Małochleb, Tereny pierwotne, „Odra” 2008, nr 2, s. 103.

14 Tamże.
} 
z zachodnim dziedzictwem kultury śródziemnomorskiej, Wilk zaś wyraźnie opowiada się za Wschodem. To właśnie Wschód jest emocjonalnie i duchowo bliższy Wilkowi, pisarz dystansuje się natomiast od kultury Zachodu. Europejczycy - zdaniem autora Wilczego notesu - są barbarzyńcami w ścisłym tego słowa znaczeniu, przynosząc ze sobą jedynie zniszczenie, dewastację naturalnego środowiska i śmierć. Podążając tropem Saamów, Wilk trafia na Półwysep Kolski, stanowiący małą ojczyznę Saamów. Ukazując ich tragiczne losy w czasach carskiej Rosji, później dramatyczne położenie w okresie komunizmu, kiedy hodowlę renów miały przejąć sowchozy, autor rejestruje proces powolnego obumierania kultury Saamów, której nieśmiałe próby odradzania w ostatnich latach traktowane są przez Rosjan jako tendencje separatystyczne. Marcin Wojciechwoski zauważa, że Tropami rena można traktować jak opis świata postkolonialnego, niewiele różniący się od wędrówek Kapuścińskiego po Afryce ${ }^{15}$. Saamom - podobnie jak Afrykańczykom - współczesna cywilizacja ma niewiele do zaoferowania. Wybór dziewiczej Północy, nieskażonej jeszcze zachodnim konsumpcjonizmem, w przypadku Wilka staje się zatem, przynajmniej do pewnego stopnia, wyborem aksjologicznym.

Źródeł fenomenu prozy Wilka, wywołującej często skrajne reakcje - od zachwytów po pełne irytacji odrzucenie - doszukiwać się chyba można nie tyle w samej tematyce jego książek, których kulturowa materia jest dla przeciętnego czytelnika - i to w najlepszym razie - dość mgliście znana i ezoteryczna, co raczej w konsekwentnie budowanej mitologii Północy, z którą łączy się radykalna filozofia „życiopisania”. Zakłada ona poświadczenie tekstu egzystencjalnym wyborem autora, jakim stała się ucieczka od zachodniej cywilizacji i osiedlenie na dalekich rubieżach północnej Rosji. W ten sposób autor gwarantuje własnym doświadczeniem, życiowym zaangażowaniem prawdziwość dokonywanych obserwacji. Tadeusz Komendant zauważa, że tym samym Wilk wypełnia ważną lukę w polskiej literaturze, w której „zawsze cierpieliśmy na niedostatek czysto ludzkiej perspektywy”"16. Zdaniem krytyka, autor Tropami rena odrzucił filozofię podróży, rezygnując z mapy na rzecz terytorium: „Żywot nomady, oglądanie świata z breughlowskiej perspektywy odrzucił na rzecz wrastania $\mathrm{w}$ terytorium [...]. Zrobił to, co niegdyś Bobkowski uciekający z Europy do Gwatemali. Była to decyzja egzystencjalna"17. Wniosek ten zdaje się potwierdzać sam autor, przyznając, że dopiero kiedy znalazł stałą przystań, zaczął obejmować Rosję całościowo: „Wędrując, poznałem ją fragmentarycznie i nie potrafiłem

15 M. Wojciechowski, Wilk wśród renów, "Gazeta Wyborcza” 2007, nr 248 z 23 września, s. 22.

16 Zob. T. Komendant, Sołowki - Wisła, „Twórczość” 1999, nr 3, s. 97.

17 Tamże, s. 100. 
z tych elementów ułożyć puzzli"18. W cyklu północnym Wilka, na co zwraca z kolei uwagę Aleksandra Chomiuk, „"przeżyć Rosję» oznacza żyć tak, jak żyją zwykli Rosjanie, zanurzyć się $\mathrm{w}$ rosyjską codzienność $\mathrm{w}$ jej wymiarze materialnym i duchowym"19. Badaczka zauważa, że nie zapobiegło to, niestety, ugrzęźnięciu w schematach dorównujących "swą banalnością tym o tajemniczej rosyjskiej duszy, o bezkresie albo o pałubiczności tamtejszego świata $[\ldots]^{\prime \prime 20}$.

Teksty Wilka nie roszczą sobie pretensji do obiektywnego opisu rzeczywistości, są przesycone subiektywną perspektywą, naznaczone zostały osobistym piętnem autora. Założenie domu na dalekiej Północy można traktować jako próbę odnalezienia swojego miejsca w świecie, jako wyraz potrzeby zakorzenienia, odzyskania poczucia jedności z naturą, zespolenia ze światem. Osiedlenie się na północnych krańcach Rosji - na Sołowkach, podróże jachtem po Morzu Białym i po Kanale Białomorskim - stają się dla Wilka - jak to ujmuje jedna z badaczek jego twórczości - „próbą zaspokojenia egzystencjalnych tęsknot i konfrontacją z własnym przeznaczeniem" ${ }^{21}$.

Dla Szczepańskiego wyprawa na Spitsbergen była konfrontacją z pustką bezkresnych arktycznych przestrzeni. W prozie Wilka pojęcie pustki ma przede wszystkim wymiar duchowy, sens metafizyczny. Pustka dalekiej Północy to „żywy obraz całości" [TR, s. 32]. Zmierzenie się z nią jest doświadczeniem oczyszczającym, odtrutką na zagubienie w cywilizacyjnej obfitości rzeczy. Kontemplacja pustki w przyrodzie staje się drogą do wewnętrznego scalenia, do odzyskania duchowej równowagi. Przyrodę postrzega Wilk jako całość, rozkład przynosi historia: „Tak zwany historyczny postęp prowadzi do rozpadu pierwotnej harmonii, a tym samym okalecza współczesnego człowieka. Jedynie w kulturach archaicznych, które przetrwały do naszych dni, zachowało się to poczucie jedności" [TR, s. 32]. Wilk swoją postawą zdaje się realizować program zawarty w głośnym manifeście geopoetyki Kennetha White'a: „Jeśli człowiek współczesny mówi: «Ja jestem, a świat jest dla mnie», to wyznawca geopoetyki powie: «jestem w świecie - słucham, patrzę; nie mam tożsamości, jestem grą energii, zbiorem możliwości»" 22 .

18 Piękno ze śmiercią w tle. Z Mariuszem Wilkiem rozmawia T. Z. Zapert, „Wyspa” 2007, nr 2, s. 101.

19 A. Chomiuk, Rosja „poza bedekerem”. Uwagi na marginesie „cyklu pótnocnego" Mariusza Wilka, „Białostockie Studia Literaturoznawcze. Rocznik Wydziału Filologicznego Uniwersytetu w Białymstoku" 2010, nr 1, s. 123.

20 Tamże, s. 124.

21 Zob. E. Pogonowska, W lustrze świata, „Kresy” 2007, nr 1-2, s. 207.

22 K. White, Wstęp do geopoetyki, w: Poeta kosmograf, wybór, oprac. i przekład K. Brakoniecki, Olsztyn 2010, s. 74. 
W prozie Wilka zarysowuje się bardzo wyraźnie coś, co można określić mianem mistyki Północy. Wędrówki Wilka są bowiem nie tylko eksploracją egzotycznych krain, ale uzyskują również wymiar egzystencjalnego, a także duchowego wtajemniczenia. Rzeczywistość często odsłania swój ukryty szyfr, epifanię można przeżyć, obserwując na przykład taflę jeziora Karelii, w której autor dostrzega „oczy innego świata” [W, s. 200]. Autor Wilczego notesu wyczulony jest na zmysłowy konkret rzeczywistości. Sensualną urodę świata próbuje uchwycić przez rejestrację momentalnych wrażeń, które stają się często - podobnie jak w przypadku Szczepańskiego - „małymi iluminacjami”, wyrywającymi podmiot z normalnego strumienia rzeczywistości. Wilk również chce zajrzeć za „podszewkę świata”, otrzeć się o metafizyczną tajemnicę. Stając się przewodnikiem po ezoterycznych kultach, pogańskich wierzeniach czy szamańskich rytuałach ludów Północy, sam - w pewnym sensie - aspiruje do roli "guru”. Akcentowanie rewelatorskiego wymiaru swych poznawczych, estetycznych i metafizycznych inicjacji oraz przekonanie o ekskluzywności własnej „tropy” - tak drażniące wielu recenzentów - E. Pogonowska uważa za prowokację autora - inna rzecz, czy do końca świadomą ${ }^{23}$. Jerzy Pilch w głośnej, zjadliwie krytycznej recenzji Wilczego notesu, która notabene wywołała burzliwą dyskusję, przysparzając rozgłosu książce, stwierdzał, że Mariusz Wilk, pragnąc gorączkowo „całą prawdę o Rosji powiedzieć, samym sobą Rosję zasłania [...] całej prawdy powiedzieć się nie da, autor posiadł ją wprawdzie, ale jest ona tak ogromna i tak niepojęta, że zwykłym zjadaczom chleba można co najwyżej dać jej „abrys”, protekcjonalnie odpowiedzieć na ich frajerskie pytania [...]"24. Również Dariusz Nowacki - w skądinąd pochlebnej recenzji Domu... - zwracał uwagę na dezynwolturę autora i pewien brak emocjonalnej powściągliwości: „Wprawdzie w dwu poprzednich książkach Wilka również można wyśledzić wątki autokreacyjne, jednak w Domu... zostały one wyraźnie uprzywilejowane. W pewnym miejscu Wilk notuje: «Północ to moja fabuła!» Po lekturze najnowszej książki chciałoby się rzec, że to za skromnie powiedziane. Zawołanie powinno brzmieć: «Północ to ja!»25. Adam Pomorski, podobnie jak Pilch, oskarżał wręcz Wilka o grafomanię: „Wiedza tajemna Wilka od lat budzi wątpliwości. [...] Dowodem prawdziwości relacji i tez Wilka ma być podejrzany autentyzm językowy. Barbaryzmy rosyjskie (najprostsze wyrazy podane bez słownikowych objaśnień) uzasadniają tu łamanie gramatyki i składni polskiej. Wobec północnego pejzażu obowią-

23 E. Pogonowska, W lustrze świata, s. 230.

24 J. Pilch, Ucha pycha, "Tygodnik Powszechny" 1998, nr 48, s. 16.

25 D. Nowacki, Pótnoc to ja!, "Gazeta Wyborcza” 2006, nr 125 z 30 maja, s. 14. 
zuje retoryczna wzniosłość lub tylko styl pokracznie kwiecisty" ${ }^{26}$. Z drugiej strony wielu badaczy rozpływało się nad stylistycznymi urokami tej prozy w swoistym volapüku językowym, dostrzegając jeden z jej największych artystycznych atutów. Nowacki w geście językowym Wilka widział np. mocny znak autorski, służący ustanowieniu własnej rzeczywistości ${ }^{27}$. Wychodząc od zasady Wittgensteina, że "granice mojego języka są granicami mojego świata” Wilk dokonuje - jak określa to jedna z badaczek - „radykalnej językowej wolty, tworząc w odwołaniu do słowiańskich podstaw polsko-rosyjskiej wspólnoty własny glosariusz otwierający «w tekście - okna do innej (nie zachodniej...) rzeczywistości» [W, s. 179]"28. Anna Sobieska dowodzi z kolei, że zobaczenie i zrozumienie Rosji jest dla Wilka równoznaczne z koniecznością porzucenia własnego języka i związanej z nim wizji rzeczywistości ${ }^{29}$. Takie nasycenie tekstu wszelkiego rodzaju rusycyzmami i archaizmami budzić może jednak wątpliwość, czy nie jest to zabieg służący w istocie przesłonięciu pewnych niedostatków stylistycznych autora. Konsekwentne przeświadczenie o nieprzekładalności pojęciowego świata obcej kultury, musiałoby wszak prowadzić do wniosku, że jedynym wyjściem pozostaje pisanie o niej w jej własnym języku. Radykalnym rozwiązaniem w sytuacji Wilka byłoby przejście na rosyjski. Na zasadzie analogii nietrudno wyobrazić sobie, jak wyglądałyby książki Kapuścińskiego o Afryce, napisane w podobnej manierze stylistycznej, gdyby np. w Hebanie co drugie zdanie ubarwione zostało wtrętem z języka suahili. Można jedynie zadać retoryczne pytanie, czy wtajemniczenie czytelników w świat afrykański byłoby wówczas istotnie głębsze?

O ile w reportaże Szczepańskiego wpisany był bardzo dyskretny autoportret pisarza, o tyle $\mathrm{w}$ prozie Wilka mamy do czynienia $\mathrm{z}$ ostentacyjną wręcz autokreacją i to sam autor staje się głównym bohaterem podróżniczych opowieści, nie kryje zresztą tego, nie bez kozery przywołując w Wołoce słowa Claudio Magrisa: „Podróżnik opisuje ten świat i w końcu rozpoznaje się w jego lustrze, zupełnie jak ów malarz z opowiadania Borgesa, który maluje pejzaż: góry, morza rzeki, na koniec zaś spostrzega, że namalował własny obraz" [W, s. 60]. Obraz autora Zatoki był ledwie widoczny w tekście, Szczepański zacierał za sobą ślady, Wilk - przeciwnie - nieustannie wysuwa się na pierwszy plan. W strategię autokreacji zdaje się również wpisywać zawarta w książkach dokumentacja zdjęciowa, przedstawiająca pisarza na tle północ-

26 A. Pomorski, Wilcze doty, „Rzeczpospolita” 2006, nr 205 z 2-3 września, s. A 12.

27 Zob. D. Nowacki, Pótnoc to ja, s. 14.

28 A. Chomiuk, Rosja "poza bedekerem", s. 124.

29 Zob. A. Sobieska, Wołoka, "Zeszyty Literackie” 2006, nr 1, s. 195. 
nej przyrody - a to medytującego w pozycji kwiatu lotosu, innym razem refleksyjnie wpatrzonego gdzieś w dal. Nie chodzi tu chyba jedynie o zabieg marketingowy. Wilk staje się $w$ pewnym sensie bohaterem literackim swoich książek, "swobodnym jeźdźcem” podążającym własną tropą.

Obok mistycyzmu Północy, duchową aurę tekstów autora Tropami rena (decydującą, jak wolno domniemywać, o ich czytelniczej atrakcyjności) tworzy bowiem również, zapożyczona od Chatwina, angielskiego pisarza i podróżnika oraz od mistrzów dalekowschodnich systemów religijnych - teologia Drogi albo raczej teologia włóczęgi jako sposobu na życie. Wilk przyznaje, że Ścieżki śpiewu Chatwina nosi zawsze przy sobie i traktuje niemal jak prywatną Biblię [TR, s. 137]. Zaznacza wszakże, iż sami nomadzi odżegnują się od jakichkolwiek systemów religijnych - nie stawiają katedr, nie wznoszą ołtarzy, nie czczą wizerunków, nie całują ikon: „Ryt zastąpili wędrówką. Do Drogi nie można modlić się w kościele. Drogę należy przejść samemu i wyśpiewać [TR, s. 138]. Wilk powołuje się na teorię Chatwina, wedle której rytm chodzenia tkwi $\mathrm{w}$ naszych genach, $\mathrm{w}$ archetypicznej pamięci. To rytm cywilizacji wyparł go ze świadomości, wywołując splin. Dlatego najlepszym lekarstwem na depresję, wywołaną przez osiadły tryb życia, jest zdaniem pisarza - podróż [TR, s. 138]. Chatwina Wilk określa mianem włóczęgi, nadając temu słowu szlachetną konotację: „Włóczęga to człowiek, który wyłania się z Drogi, i Droga, która z człowieka wyrasta" [TR, s. 140]. Swoje wywody Wilk często z solenną powagą inkrustuje cytatami ze swoich ulubionych autorów - w stylu: „Nim zaczniesz kroczyć drogą, sam musisz stać się Drogą" czy "Życie jest jak most - przejdź na nim na drugą stronę, ale nie buduj na nim domu" [TR, s. 137-138]. Życie „w drodze” staje się wyborem egzystencjalnym, którego sens wykracza poza literackie i czysto poznawcze aspekty. To rodzaj eskapizmu, ucieczki od cywilizacji, poszukiwanie autentyczności połączone z kontestacją konsumpcyjnego stylu życia. Tym samym Wilk wpisuje się w kontrkulturowy wzór, który we współczesnej literaturze zapoczątkowało pokolenie beat generation, mające licznych późniejszych kontynuatorów. Jest $\mathrm{w}$ jego książkach podobna aura mistycznych wtajemniczeń, konsekwentny bunt przeciwko establishmentowi, odnalezienie azylu na peryferiach cywilizacji.

Autor Tropami rena nie chce zamykać swojej religijności w ramach żadnego sztywnego systemu religijnego. Deklaruje, że wszystkie religie, oprócz tych, które nawołują do walki z innowiercami, są mu jednakowo bliskie od szamanizmu Saamów do milczącej reguły Thomasa Mertona: „W religii, jak i w sztuce, podziwiam wzlot ludzkiego ducha, czy to będzie bizantyjska ikona, czy lamajska thanka, cerkiew Przemienienia Pańskiego na Kiży, buddyjska świątynia w Polonnaruwie, czy katedra Notre Dame w Pa- 
ryżu" [DO, s. 31]. Doświadczenie religijne jest dla Wilka pierwotnym, nieusuwalnym elementem rzeczywistości, nadającym jej sens, chroniącym przed degradacją człowieczeństwa. Dlatego uważa, że pejzażowi północnemu należy przywrócić jego sakralny wymiar.

Północ, bardzo silnie w prozie Wilka zmitologizowana i „uromantyczniona", jest dogodnym punktem obserwacyjnym, z którego - niczym z jakiegoś niebotycznego szczytu Alp - dobrze widać cały świat ścielący się w dole: „Północ - to moje koczowisko, obszar penetracji. Północ - to moja fabuła!" [DO, s. 46]. Doświadczenie Północy uczy dystansu. Zetknięcie z plemieniem Saamów pozwoliło autorowi zajrzeć do wnętrza "własnej studni”. Stykając się z nomadami Północy, zadaje sobie często pytanie o własną tożsamość kulturową i duchową, o granice własnego „ja”. Kategoria „narodu” czy "polskości” okazuje się w tym przypadku za ciasna, zbyt wąska, zanadto ograniczająca. Trzeba w tej sytuacji odnaleźć jakiś szerszy układ odniesienia, wspólny dla całej rodziny ludzkiej: „Uważniej też przyjrzałem się ich wierze pogańskiej, z której nas wychrzczono zaledwie tysiąc lat temu. Nie chodzi wcale o magię myśliwską czy szamańskie loty, ale o tę pierwotną intuicję panteistyczną stojącą u źródeł metafizycznych poszukiwań homo sapiens (ich zwieńczenie znajduję $\mathrm{u}$ dawnych mistrzów tao), póki jej nie wyparły dymy kadzideł, dogmaty, egzorcyzmy i święte księgi późniejszych religii" [TR, s. 77]. Wyprawa na Północ jest zatem również wędrówką w czasie, cofnięciem się do religijnego matecznika ludzkości, co Wilk opisuje jako doświadczenie oczyszczające, wyzwalające z ciasnych ram ortodoksji, pozwalające odkryć poczucie duchowego pokrewieństwa z przedstawicielami dalekich - na pozór - kultów i rytów. Wędrówka ma zatem wymiar sakralny, a sam autor - niczym Pielgrzym z Sonetów krymskich Mickiewicza - dociera do granic niewypowiadalnego.

W pisarstwie Wilka - w konfrontacji ze Szczepańskim - ujawnia się dobitnie bardzo silna tendencja współczesnej prozy podróżniczej, którą można określić mianem antropologizacji reportażu. Dziś nie wystarczy już tylko dotrzeć do miejsca, o którym się pisze, trzeba je przyswoić, zinterioryzować, uczynić własnym, wcielić się w rolę ",badacza terenowego", który dogłębnie poznaje historię i kontekst kulturowy opisywanej społeczności. Przede wszystkim należy jednak uwiarygodnić oraz nasycić tekst prawdą własnej egzystencji. Wędrówka ku egzotycznym krainom i ludom je zamieszkującym - w swym głębszym wymiarze - służy przede wszystkim odnalezieniu siebie oraz swojego miejsca w świecie ${ }^{30}$. Szczepański, choć zachowywał pewien dy-

\footnotetext{
30 Zob. Na Sołowkach można zobaczyć siebie. Z Mariuszem Wilkiem rozmawia Alina Kietys, „Sycyna” 1998, nr 16, s. 1, 3-4.
} 
stans wobec śródziemnomorskiego dziedzictwa, poszukując inspiracji w bardziej egzotycznych kręgach kulturowych, wracał ze swoich peregrynacji do Europy jak do domu, Wilk do kultury Zachodu odwraca się plecami.

Pobyt na dalekiej Północy pozwolił autorowi Wołoki zdobyć nowe punkty widzenia, odkryć nieprzeczuwane horyzonty, zobaczyć ludzką historię w kategoriach długiego trwania wykraczających poza przyswojone kulturowe kanony i stereotypy: „Bez wątpienia wyjadę stąd inny, niż tu przyjechałem: to znaczy $z$ inną perspektywą, bardziej cofniętą w czasie. O ile kiedyś krąg mego świata oświetlało słowo pisane, o tyle teraz jąłem dostrzegać także to, co ukrywa się w milczeniu" [TR, s. 77]. Warto z Wilkiem wsłuchać się w to milczenie.

\section{"Północ - to moja fabuła"}

Polar Epiphanies of Jan Józef Szczepański and Mariusz Wilk

\section{Summary}

The article is a comparative study of Zatoka Białych Niedźwiedzi by J. J. Szczepański and Dziennik pótnocny by Mariusz Wilk. The analysis attempts to define the character of travelogue in both authors' work, and to employ their work in order to outline the changes which the travel discourse has undergone over the recent years. 
